\title{
Guiding the Students in High School by Using Machine Learning
}

\author{
Mustafa Ababneh, Aayat Aljarrah, Damla Karagozlu, Fezile Ozdamli
}

\section{Department of Computer Information System, Near East University, Nicosia,Cyprus, Mersin 10, Turkey}

\begin{abstract}
Machine learning is considered the most significant technique that processes and analyses educational big data. In this research paper, many previous papers related to analysing the educational big data that uses a lot of artificial intelligence techniques were studied. The purpose of the study is to identify weaknesses and gaps in previous researches. The results showed that many researches highlighted early expectations for academic performance. Unfortunately, no one thought of finding an effective way to guide high schooled students to reach their appropriate majors that can be suitable to their abilities. Those students need to be guided to pass this sensitive phase with high efficiency and good results. Thus, this school level is considered as the starting point for students' academic lives, professional, and future success.
\end{abstract}

Keywords - Big Data Analysis, education, machine learning, Student information system, student direction.

\section{Introduction}

Now in the era of technology and data where digital devices including smart machines like the computer, tablets, and smartphones are sprayed everywhere. These devices collect a huge amount of various data that can contribute to discovering unknown patterns and directions [1].

DOI: 10.18421/TEM101-48

https://doi.org/10.18421/TEM101-48

Corresponding author: Mustafa Ababneh, Department of Computer Information System, Near East University, Nicosia,Cyprus, Mersin 10, Turkey.

Email: 20194017@std.neu.edu.tr

Received: 10 September 2020.

Revised: 25 December 2020.

Accepted: 30 December 2020.

Published: 27 February 2021.

(cc) BY-NC-ND (C) 2021 Mustafa Ababneh et al; published by UIKTEN. This work is licensed under the Creative Commons Attribution-NonCommercial-NoDerivs 4.0 License.

The article is published with Open Access at www.temjournal.com
The rapid spreading of such data leads to creating the new developed techniques specialized in improving and analyzing data [2]. The methods of data analysis are classified into statistics methods [3], artificial intelligence [4], and machine learning [5], where all these techniques work for the goal of pattern extraction, expecting behaviors or describing directions relying on the wanted goals [1].

The use of big data has brought a lot of changes in most fields of human endeavor including the health sector [6], both economic and commercial majors [7]. Also, education is considered as the most prominent areas affected by this change. In recent years, the educational institutions became able to collect, use, and exchange the data easily with high speed more than any previous time [8], so such institutions include: primary schools, high schools, universities, and the educational service providers online.

Nowadays, the learning analysis and educational data mining play an important role in organizing the progress of the educational process where this data concentrates on explaining the way of getting a precious knowledge in order to apply the learning automatically, and make judicial interventions for the process and to use it for expecting various decisive educational results such as the performances ([9], [10]). When it comes to the learning analysis, it focuses on the way of having optimism in applying the process of learning by the help of data analysis [9]. To illustrate the learning analysis, it is concentrating on the data that is specialized in making and giving some decisions related to both learning and teaching processes [10]. Thus, data analysis may have a big effect on all stakeholders starting from teachers, to students, to the trainers of leadership, till the educational administration.

Although there is a variety and a spread in the researches that were done to improve the learning management system, many students still make mistakes about the suitable major for their abilities which highly effects on their practical and scientific life. This bad choice for many students in choosing the appropriate field, especially in high school, leads them to get very low grades or even failure in this major. This period is considered as the actual starting 
point for students and their educational and professional careers in the future. Therefore, this study aims to investigate the cause of these problems by using specific techniques for analyzing data by using machine learning. Also, gaps in previous studies were identified with giving suggestions in the future. As a result, in this study two questions are asked in order to fill these gaps. Firstly, how to use data analysis techniques such as artificial intelligence and machine learning in the field of education? Secondly, how does the data on the student information system (SIS) contribute to the data analysis process?

\section{Related Work}

Any educational institution receives a huge amount of information every day. It gets some details about the absence, the participation, and the exams' results. In addition, the students can evaluate their teachers and lecturers by giving details about their social and economic situation, and they can share their levels of satisfaction with the education they received. Also, the use of the scientific methods is used to collect data and analyze it where educational institutions can start producing more personalized education.

\section{The Student Information System in Learning Analysis}

The Special data for the electronic learning activity has many features similar to the ones in the big data because it contains thousands of dealings for each student, precisely in the actual time taken from different sources and websites [11]. Generally, elearning concentrates mainly on the results of the analysis process, besides the information resulted from polls and questionnaires without high-quality datasets. A few researchers aim to discover the students' way of behaving inside the e-Learning in order to help the process of analyzing the learning methods. After collecting data by researchers from the LMS (learning management system) follows the goal which deals with putting an eye on the behavior of the users, namely students. Also, it reaches to the documents about students for both aspects; social and demographic sides. These aspects are taken from the students' profiles and the system of learning management to sign in the structural data for the purpose of studying behaviors of the students, especially from Moodle [12].

\section{Artificial Intelligence Technique}

Recently artificial intelligence techniques such as machine learning and data mining have been applied to several fields. There are many benefits of artificial intelligence in all areas of educational, medical, health, marketing, and many other fields, as it can deal with huge amounts of data super-fast. Also, artificial intelligence software can also help in making decisions, and using machine learning one can also predict many future things which is shown in Table 1.

\section{Machine Learning in Education}

The field of education is considered as a very active major that took the attention which continues to be enhanced by time. Moving from traditional education to the e-Learning one, a lot of helpful techniques were used in order to present better quality experiments to develop the whole major. By mixing the human with the machine (the creature with his creator), this can be very helpful to get good results [14], which will enrich the process of learning. Also, machine learning has the ability to learn from any experience [15]. A lot of machine learning samples exist, but the most known or popular ones are of both kinds; supervised and unsupervised. The first one is specialized in helping the samples by using the dataset, but the second one works by following some results with a self-learning method from the sample itself [15].

\section{Educational Success}

It is a conclusive staple for high studies in colleges and universities. It is the main standard for evaluating the education's equality in institutions [9]. It can be clarified by using a lot of definitions, especially in Literature [16]. It was compounded from literature to be defined as: "academic achievement, engagement in educationally purposeful activities, satisfaction, acquisition of desired knowledge, skills and competencies, persistence, attainment of educational outcomes, and post-college performance." It is noticeable that this previous definition is dimensioned by having many forks. However, in a research aimed to create a developed one that concentrates only on more significant aspects such as: " Academic achievement, satisfaction, acquisition of skills and competencies, persistence, attainment of learning objectives, and career success" are to be taken by authors in [12]. 
Table 1. Presents many papers explaining the use of Artificial Intelligence in various fields

\begin{tabular}{|c|c|c|}
\hline Authors / Year & Objective & Field \\
\hline $\begin{array}{l}\text { Kavakiotis et } \\
\text { al., } 2017 \text { [7] }\end{array}$ & $\begin{array}{l}\text { The study highlights } \\
\text { managing a coordinated } \\
\text { revision of the } \\
\text { applications used in ML } \\
\text { and the tools used in Data } \\
\text { Mining and Health Care } \\
\text { Management. }\end{array}$ & Healthcare \\
\hline $\begin{array}{c}\text { Massaro, } \\
\text { Maritati, \& } \\
\text { Galiano, } 2018 \\
{[8]}\end{array}$ & $\begin{array}{l}\text { This study shows creating } \\
\text { a deep learning sample } \\
\text { performance for expecting } \\
\text { an appropriate algorithm } \\
\text { used for sales } \\
\text { expectations. }\end{array}$ & Business \\
\hline $\begin{array}{c}\text { Adekitan, } 2018 \\
\text { [9] }\end{array}$ & $\begin{array}{l}\text { The paper describes the } \\
\text { relationship among } \\
\text { perceptive acceptance } \\
\text { needs for students and } \\
\text { their academic results and } \\
\text { performances for the } \\
\text { freshmen students, } \\
\text { precisely. This is done by } \\
\text { using the students' CGPA } \\
\text { and by checking their } \\
\text { rates of degrees, } \\
\text { especially by using about } \\
6 \text { algorithms specialized } \\
\text { in data mining in two } \\
\text { platforms Orange and } \\
\text { KNIME. }\end{array}$ & Education \\
\hline $\begin{array}{l}\text { Varol, Ferrara, } \\
\text { Davis, } \\
\text { Menczer, \& } \\
\text { Flammini, } \\
2017 \text { [13] }\end{array}$ & $\begin{array}{l}\text { Creating new algorithms } \\
\text { has led to creating an } \\
\text { automatic exchanging } \\
\text { which contributes by itself } \\
\text { to make sudden crashes in } \\
\text { the stock's market in the } \\
\text { United States. }\end{array}$ & Marketing \\
\hline
\end{tabular}

\section{Methodology}

After understanding the significance of the research subjects, many published papers related to this special topic were searched in a lot of literary sources. In order to get very beneficial results, the process of working was divided into phases or stages. The first step is defining the topic of the research. Then, the searching in resources and the collecting of many researches related to analyzing data are made to get good results. After that, each study has to be divided and analyzed separately in order to know the purpose of the study and the results too. Gaps are also clarified in each study where at the end suggesting solutions to these gaps is necessary to be done.

\section{Data Collection}

In this step, a lot of popular, important and comprehensive databases were searched. These databases are related to education, development, and the big data field. Four databases were searched (Web of science, science direct, IEEE, SpringerLink), and became the search engine that targets research, especially in the period from 2009 to 2020. They are chosen to search either by the abstract, the title, or the keywords. These are considered as search engines where some written words are given to be applied for searching like: ("Big Data Analysis" and "Education" and "machine learning" or "learning analysis" or "learning management system" and "Educational data mining" or "sis" and "student direction" ). As a result of the research 308 items from all databases are found, as shown in Figure 1.

- 159 articles were obtained from the Web of Science database, 27 of which are open access including 18 articles and 9 proceeding papers.

- 8 articles were obtained from SpringerLink, including 2 articles and 6 chapters.

- 6 articles were obtained from IEEE, including 2 articles and 4 Conferences.

- 135 articles were obtained from Science direct, 33 of which are open access including 28 research articles and 5 review papers.

\section{Data Filtering and Selection}

In this stage, articles were divided by being put under a filtering process to choose the most related ones, especially by using concepts like student's interests, learners' talents, students' talents, student's success, academic learning, academic success, and etc., (Figure 1).

These articles are analyzed again to get only 52 articles. After doing some analysis, some researches were created to produce analysis systems of education to be included. Only 14 articles were left that need to be analyzed cautiously (Table 2 ).

\section{Data Analysis}

This stage is considered as a very important one where after collecting data, filtering it, and choosing articles that will be used; we analyze each article including its goals and results. Also, articles are put in groups depending on their point of view and similarity, besides specifying the gaps inside each article. 


\section{Results and Discussion}

Many researchers aim to improve the learning process by producing methods for students' education. In one of these researches, the researchers create an algorithm that works to collect the academic achievement "GPA". This process is done by studying the situations towards many aspects such as the educational patterns in the academic achievement and the effect of the Academic achievement's level on the groups and the learning methods for students. The data was collected from schools and colleges in Thailand precisely the University of Phayaoin Thailand, and the algorithm was proved by using clustering analysis. Although this algorithm proved its success that the research here was confining only the data taken from one side which is the students', while the other related sides were ignored [17].

The study is based on evaluating and predicting the students that are at risk of failure or being underperformance early by applying some mixed practical courses. The neural network's algorithm is used, besides collecting data from the "learning

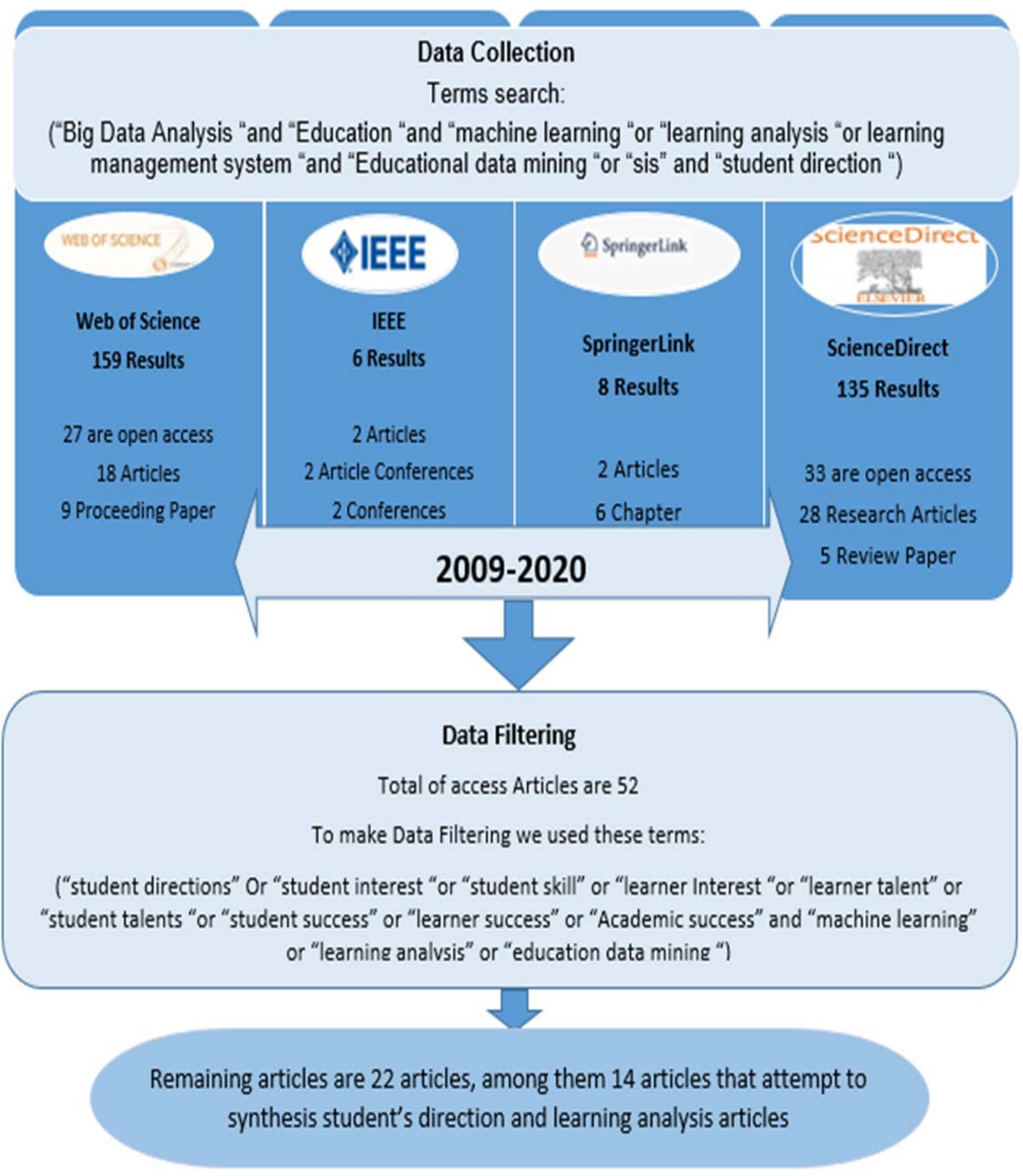

Figure 1. Data collection and filtering 
management system" and from the results of the online tests or the midterm ones in Kumamoto university in Japan. It turns out that those two algorithms did not use enough data. Here is the principle: the more data is used, the more accurate the results will be. However, in contrary to the previous studies, here, the data was gathered from teachers ignoring the students' side [18].

In another study, the researcher aims to distinguish the students that are unable to compete with the programming courses instead of evaluating their performance by using the clustering method. The researcher collected the data from the SIS or the students' profiles. In this case, the researcher suggested a method to expect the students' dropouts from the e-Learning systems where it was revealed that the use of $\mathrm{K}$ _means the algorithm does not give detailed results as well as the lack of entered data that limits the accurate results [19].

Moreover, many research papers predict the students' behaviors. This is done in order to take the necessary solutions and suitable strategies to improve the performance of the weak students before being too late. In such a case, the researcher designed a system of "Neural Fuzzy Inference System" to expect the students' performance relying on their previous performances. For instance, a group of data in one Indian public university was applied where the results were very satisfying. However, according to the researcher's analysis, if the number of the data was higher, the results will be more detailed and accurate [20].

In addition, one researcher has created an algorithm to enhance the students ' academic performance by checking the late homework. The researcher collected the data from putting the students into groups in a specific mixed educational course via the internet precisely by using a scholar course. However, this algorithm faced many problems especially when it comes to increasing the classes of students. In other words, the algorithm does not work efficiently when it deals with big data [21].

Also, in this review article, the researcher studied the related research that is very related and close to the problem of expecting academic success by using the machine learning algorithm specifically for the last 5 years. The purpose of this study was to improve a prediction sample that works very hard to improve the students' steps towards success by using the technique of "Educational Data Mining". This study is confined only to the college students in the Bachelor's degree. All their data was gathered from the students' information systems or the SIS [22].

In another research paper, the researcher created a visual analysis method that is called "performance Vis". It is used to analyze the data of students' performance over time relying on three main aspects: the students' characteristics, following the homework and designing the exams' questions. This method may help students in previewing their previous performances besides understanding the exact points of difficulties faced in this course. Also, it can help teachers and supervisors in determining the students that may fail in a very short time. This method was designed relying on stored data in the students' information system. Unfortunately, it will be better if it was designed to coincide with the course while it is still active. Thus, the benefits will be higher if the students can see their weaknesses at once. As a result, they can handle them while taking the course [23].

The researcher here went to prospect the data that guides students. One algorithm was built to achieve this goal. It was a methodology of "RISP_DM" which was applied to data taken from the SIS. This algorithm aims to guide college students in the process of registering to their materials and courses. It helps students to choose the best course that corresponds to their abilities. After evaluating this algorithm, it was noticeable that it got perfect results. Nevertheless, students' grades, in a very short period, cannot be taken as a standard to judge their success and their failure [24].

Another research paper appeared that aimed to evaluate and judge the students' skills; "SelfRegulated Learning ". It depends on the E-Learning courses using techniques such as "Educational Process Mining". A course log file was analyzed through the internet for the college students in Spain. The study contained a pretreatment in order to perform the process of "mining" followed by a discovery to it. The algorithm of "Inductive Miner" was used, too. Although strong results were achieved for this study, the data that analyzed was only taken from the third-year students. Thus, this made a challenge compared to the freshmen's results which probably will be very different [25].

Another important study created an algorithm that highlights the expectancy of the final performance for the students by using: "Artificial Neural Network" in the online learning environment. This algorithm relies on analyzing many variables such as the number of attendees and the time spent for Students' browsing. Though the results were very good for such an algorithm, we think it will be better to increase the number of the analyzed variables in order to help in increasing the accuracy of the research [26].

Like any other research paper, this algorithm depends on big data to expect the academic performance, too. Data was taken from about 141 students in west Scotland University from the system of: "SIS, LMS, Decision Tree, and Artificial Neural 
Network". This algorithm aims to help in providing an early prediction of the students that may be at risk of dropping out from higher education where a model of "Multi-model Heterogeneous Ensemble Approach" was improved to help in such cases. Like other studies, this one may be better if it had many numbers of variables to be analyzed for getting more honest and reliable results [27].

The process in the earlier prediction for the academic levels and performances were done for students to contribute in developing the educational status, and to be evaluated easily by their teachers and lecturers. However, in this process, teachers are able to take some steps especially when it comes to the appropriate teaching style. Thus, the researcher built a sample called "Fuzzy Logic Model" that uses genetic algorithms. Also, the data is collected here by using the distance education system through analyzing the number of times a student enters the system, besides the amount of time spent using the internet. In addition, it has to be mentioned that the researcher has studied the data for 6 weeks. Then, a comparison to the real results was done at the end of the semester in which the percentage for the model's accuracy was recorded about $84.52 \%$. This model is the most accurate one, but it lacks the variety of data resources. In other words, if the data resources used in this algorithm were higher, the results would be very accurate [28].

The researches that analyzed the learning management systems were not limited only to enhance the students' performance and evaluate them, but many researches work to develop the teachers as well. They aim to improve the teachers and to evaluate their capacity too. This study was applied and tested in a Spanish University where data was collected by using MySQL. Also, to handle this data, the R_ Tools were used too, and this study is considered as a very important one to measure and develop the teacher's performance. However, it has much specific quantification. For example, teachers may not interact in the E-Learning courses which cannot be considered as a weak point, but it may be a lack of resources configured to him/her [29].

Some studies highlight evaluating the teaching methods and determining the most efficient ones in the e-Learning systems. This kind of study was applied to Bahçeşehir University on the third-year students to discover the effects of each Strategy on their performance. In this study, the importance of students' opinions was the main tool to judge it. This may weaken the results of the research because the variety and the differences in the opinions may lead to many useful results [30].
Table 2. Analyzed papers

\begin{tabular}{|c|c|c|}
\hline Title of papers & Technique & Objective \\
\hline $\begin{array}{l}\text { Students Model in } \\
\text { Different Learning } \\
\text { Styles of Academic } \\
\text { Achievement at the } \\
\text { University of } \\
\text { Phayao, Thailand } \\
\text { [17] }\end{array}$ & $\begin{array}{l}\text { Clustering } \\
\text { analysis }\end{array}$ & $\begin{array}{l}\text { Study the effect } \\
\text { of educational } \\
\text { patterns on the } \\
\text { academic } \\
\text { achievement of } \\
\text { students }\end{array}$ \\
\hline $\begin{array}{l}\text { An Artificial Neural } \\
\text { Network Based Early } \\
\text { Prediction of Failure- } \\
\text { Prone Students in } \\
\text { Blended Learning } \\
\text { Course [18] }\end{array}$ & $\begin{array}{l}\text { Artificial } \\
\text { Neural } \\
\text { Network }\end{array}$ & $\begin{array}{l}\text { Early } \\
\text { prediction to } \\
\text { identify } \\
\text { students at risk } \\
\text { of failure in } \\
\text { mixed learning } \\
\text { courses }\end{array}$ \\
\hline $\begin{array}{l}\text { Log-Data Clustering } \\
\text { Analysis for Dropout } \\
\text { Prediction in } \\
\text { Beginner } \\
\text { Programming } \\
\text { Classes [19] }\end{array}$ & $\begin{array}{l}\text { Clustering } \\
\text { Analysis }\end{array}$ & $\begin{array}{l}\text { Students } \\
\text { dropout } \\
\text { Prediction in } \\
\text { beginner } \\
\text { programming } \\
\text { courses }\end{array}$ \\
\hline $\begin{array}{l}\text { An Adaptive Neural } \\
\text { Fuzzy Inference } \\
\text { System for } \\
\text { prediction of student } \\
\text { performance in } \\
\text { Higher Education } \\
{[20]}\end{array}$ & $\begin{array}{l}\text { Neural Fuzzy } \\
\text { Inference } \\
\text { System }\end{array}$ & $\begin{array}{l}\text { Prediction of } \\
\text { learner } \\
\text { performance in } \\
\text { Higher } \\
\text { Education }\end{array}$ \\
\hline $\begin{array}{l}\text { Predicting Students' } \\
\text { Academic } \\
\text { Procrastination in } \\
\text { Blended Learning } \\
\text { Course Using } \\
\text { Homework } \\
\text { Submission Data } \\
{[21]}\end{array}$ & $\begin{array}{l}\text { K-means } \\
\text { clustering }\end{array}$ & $\begin{array}{l}\text { Predicting } \\
\text { Students' } \\
\text { Academic } \\
\text { Procrastination }\end{array}$ \\
\hline $\begin{array}{l}\text { Predicting academic } \\
\text { success in higher } \\
\text { education: literature } \\
\text { review and best } \\
\text { practices [22] }\end{array}$ & $\begin{array}{l}\text { Machine } \\
\text { learning }\end{array}$ & $\begin{array}{l}\text { Predicting } \\
\text { academic } \\
\text { success in } \\
\text { higher } \\
\text { education }\end{array}$ \\
\hline $\begin{array}{l}\text { PerformanceVis: } \\
\text { Visual analytics of } \\
\text { student performance } \\
\text { data from an } \\
\text { introductory } \\
\text { chemistry course [23] }\end{array}$ & $\begin{array}{c}\text { Visual } \\
\text { analytics: } \\
\text { PerformanceVis } \\
\text { tool }\end{array}$ & $\begin{array}{l}\text { Analysis of } \\
\text { student } \\
\text { performance } \\
\text { data from an } \\
\text { introductory } \\
\text { chemistry } \\
\text { course }\end{array}$ \\
\hline $\begin{array}{l}\text { A data mining } \\
\text { approach to guide } \\
\text { students through the } \\
\text { enrollment process } \\
\text { based on academic } \\
\text { performance [24] }\end{array}$ & $\begin{array}{l}\text { data mining } \\
\text { approach: } \\
\text { CRISP-DM } \\
\text { methodology }\end{array}$ & $\begin{array}{l}\text { Guide students } \\
\text { through the } \\
\text { enrollment } \\
\text { process based } \\
\text { on academic } \\
\text { performance }\end{array}$ \\
\hline $\begin{array}{l}\text { Process mining for } \\
\text { self-regulated } \\
\text { learning assessment } \\
\text { in e-learning [25] }\end{array}$ & $\begin{array}{l}\text { Process Mining } \\
\text { Techniques: } \\
\text { Inductive Miner }\end{array}$ & $\begin{array}{l}\text { Self-regulated } \\
\text { learning } \\
\text { evaluating } \\
\text { in e-learning }\end{array}$ \\
\hline $\begin{array}{l}\text { Predicting student } \\
\text { final performance }\end{array}$ & $\begin{array}{c}\text { Artificial neural } \\
\text { networks }\end{array}$ & $\begin{array}{l}\text { Predicting } \\
\text { student final }\end{array}$ \\
\hline
\end{tabular}




\begin{tabular}{|c|c|c|}
\hline $\begin{array}{l}\text { using artificial neural } \\
\text { networks in online } \\
\text { learning } \\
\text { environments [26] }\end{array}$ & & performance \\
\hline $\begin{array}{l}\text { Predicting student } \\
\text { academic } \\
\text { performance using } \\
\text { multi-model } \\
\text { heterogeneous } \\
\text { ensemble approach } \\
\text { [27] }\end{array}$ & $\begin{array}{l}\text { Multi-model } \\
\text { heterogeneous } \\
\text { ensemble } \\
\text { approach }\end{array}$ & $\begin{array}{l}\text { Predicting } \\
\text { student } \\
\text { academic } \\
\text { performance }\end{array}$ \\
\hline $\begin{array}{l}\text { A Genetic-Fuzzy } \\
\text { Based Mathematical } \\
\text { Model to Evaluate } \\
\text { The Distance } \\
\text { Education Students' } \\
\text { Academic } \\
\text { Performance [28] }\end{array}$ & $\begin{array}{c}\text { Fuzzy logic } \\
\text { model: Genetic } \\
\text { Algorithms }\end{array}$ & $\begin{array}{l}\text { Evaluate The } \\
\text { Distance } \\
\text { Education } \\
\text { Students' } \\
\text { Academic } \\
\text { Performance }\end{array}$ \\
\hline $\begin{array}{l}\text { The use of electronic } \\
\text { curriculums in } \\
\text { occupational } \\
\text { education to evaluate } \\
\text { and improve the } \\
\text { cognitive capacity of } \\
\text { candidate software } \\
\text { engineers [29] }\end{array}$ & $\begin{array}{l}\text { Learning } \\
\text { system }\end{array}$ & $\begin{array}{l}\text { Learning } \\
\text { methods which } \\
\text { may be used to } \\
\text { improve the } \\
\text { learning process }\end{array}$ \\
\hline $\begin{array}{l}\text { Clustering Analysis } \\
\text { for Automatic } \\
\text { Certification of LMS } \\
\text { Strategies in a } \\
\text { University Virtual } \\
\text { Campus [30] }\end{array}$ & $\begin{array}{l}\text { Clustering } \\
\text { Analysis: R- } \\
\text { Tools }\end{array}$ & $\begin{array}{l}\text { Automatically } \\
\text { classify and } \\
\text { certify teacher } \\
\text { competence in } \\
\text { LMS }\end{array}$ \\
\hline
\end{tabular}

The use of artificial intelligence and machine learning techniques in the field of education is very important and common as many researchers have been ready to employ artificial intelligence techniques to support the education system and increase academic success rates by building systems to assess students and predict their academic performance using automated learning algorithms ([17], [18]), and many researches have achieved high accuracy and one of the researches was based on (Fuzzy Logic model) using (genetic algorithm) with a high accuracy rate of $84.52 \%$ [27].

Several researches have also targeted e-learning systems to predict student performance and student assessment ([21], [25], [26]), and some studies have also focused on building a methodology in predicting student dropout rates in e-learning systems [19]. In all previous research, most data were collected from student information systems. In contrast to previous research, some studies were concerned with making use of machine learning algorithms to evaluate teachers' performance and improve their performance ([29], [30]).

The systematic review of the researches showed that there is a lack of researches targeting high school students, and no research was found that aims to guide students in high school in choosing their academic direction at this stage, while only two studies were found that guide students in the university ([22], [24]), and that it is a big gap in the development of the process of academic success as this reason is considered one of the most important reasons in conducting literary research on this topic. Also, the use of artificial intelligence techniques especially machine learning is a broad topic undoubtedly, of great importance in the field of education and it is considered the latest technology.

Previous studies also showed that the process of predicting academic success and methods of finding remedial measures to improve student performance ([9], [20], and [23]) are among the most important ways to achieve academic success. Based on this systematic review, we will suggest creating a new system to guide the students to choose appropriate branches of their scientific capability in high school dependent on their data and marks in all subjects in the previous school years.

\section{Conclusion}

Expecting students' performance early can help the universities and schools to make the right training or control. Also, guiding the students from the beginning can support planning for suitable training to improve the percentage of the students' success. Discovering the educational data can help for sure in achieving the wanted educational purposes. By using the techniques of educational data mining it is not impossible to develop samples to expect the success of learners. This study will fill many gaps in such a major, besides highlighting more research. It can help many learners and researchers to advice students and guide them easily. Therefore our future methodology is based on the establishment of a system that determines the skills and inclinations of the student in the eleventh grade according on the data and marks of the student in all subjects from the seventh grade to the eleventh grade, and thus this system is formed on submitting a direction proposal that the student has to take in the secondary stage (scientific - literary - management etc.), since many students wish to go to a direct supervision that does not suit their abilities.

\section{References}

[1]. Han, J. and M. Kamber (2006). Data Mining: Concepts and Techniques. A. Stephan. San Francisco, Morgan Kaufmann Publishers is an imprint of Elsevier.

[2]. Picciano, A. G. (2012). The evolution of big data and learning analytics in American higher education. Journal of asynchronous learning networks, 16(3), 9-20.

[3]. Hand, D. J. (1998). Data mining: statistics and more?. The American Statistician, 52(2), 112-118.

[4]. Zawacki-Richter, O., Marín, V. I., Bond, M., \& Gouverneur, F. (2019). Systematic review of research on artificial intelligence applications in higher education-where are the educators?. International Journal of Educational Technology in Higher Education, 16(1), 39. 
[5]. Kononenko, I., \& Kukar, M. (2007). Machine learning and data mining. Chichester, UK: Horwood Publishing.

[6]. Kavakiotis, I., Tsave, O., Salifoglou, A., Maglaveras, N., Vlahavas, I., \& Chouvarda, I. (2017). Machine learning and data mining methods in diabetes research. Computational and structural biotechnology journal, 15, 104-116.

[7]. Massaro, A., Maritati, V., \& Galiano, A. (2018). Data Mining model performance of sales predictive algorithms based on RapidMiner workflows. International Journal of Computer Science \& Information Technology (IJCSIT), 10(3), 39-56.

[8]. Adekitan, A. I., \& Noma-Osaghae, E. (2019). Data mining approach to predicting the performance of first year student in a university using the admission requirements. Education and Information Technologies, 24(2), 1527-1543.

[9]. Anoopkumar, M., \& Rahman, A. M. Z. (2016, March). A Review on Data Mining techniques and factors used in Educational Data Mining to predict student amelioration. In 2016 International Conference on Data Mining and Advanced Computing (SAPIENCE) (pp. 122-133). IEEE.

[10]. Du, X., Yang, J., Shelton, B. E., Hung, J. L., \& Zhang, M. (2019). A systematic meta-Review and analysis of learning analytics research. Behaviour \& Information Technology, 1-14.

[11]. Daniel, B. K. (2016). Big data and learning analytics in higher education. New York: Springer.

[12]. Purwoningsih, T., Santoso, H. B., \& Hasibuan, Z. A. (2019, October). Online Learners' Behaviors Detection Using Exploratory Data Analysis and Machine Learning Approach. In 2019 Fourth International Conference on Informatics and Computing (ICIC) (pp. 1-8). IEEE.

[13]. Varol, O., Ferrara, E., Davis, C., Menczer, F., \& Flammini, A. (2017, May). Online human-bot interactions: Detection, estimation, and characterization. In Proceedings of the International AAAI Conference on Web and Social Media (Vol. 11, No. 1).

[14]. Vaughan, J. W. (2017). Making better use of the crowd: How crowdsourcing can advance machine learning research. The Journal of Machine Learning Research, 18(1), 7026-7071.

[15]. Ababneh, M. A. K., Al-Jarrah, A. A., \& Karagozlu, D. (2020). The Role of Big Data and Machine Learning in COVID-19. BRAIN. Broad Research in Artificial Intelligence and Neuroscience, 11(2Sup1), 01-20.

[16]. Kuh, G. D., Kinzie, J. L., Buckley, J. A., Bridges, B. K., \& Hayek, J. C. (2006). What matters to student success: A review of the literature (Vol. 8). Washington, DC: National Postsecondary Education Cooperative.

[17]. Nuankaew, P., Nuankaew, W., Phanniphong, K., Imwut, S., \& Bussaman, S. (2019). Students model in different learning styles of academic achievement at the university of Phayao, Thailand. International Journal of Emerging Technologies in Learning (iJET), 14(12), 133-157.
[18]. Sukhbaatar, O., Usagawa, T., \& Choimaa, L. (2019). An artificial neural network based early prediction of failure-prone students in blended learning course. International Journal of Emerging Technologies in Learning (iJET), 14(19), 77-92.

[19]. Oeda, S., \& Hashimoto, G. (2017). Log-Data Clustering Analysis for Dropout Prediction in Beginner Programming Classes. Procedia computer science, 112, 614-621.

[20]. Maitra, S., Madan, S., \& Mahajan, P. (2018, October). An Adaptive Neural Fuzzy Inference System for prediction of student performance in Higher Education. In 2018 International Conference on Advances in Computing, Communication Control and Networking (ICACCCN) (pp. 1158-1163). IEEE.

[21]. Akram, A., Fu, C., Li, Y., Javed, M. Y., Lin, R., Jiang, Y., \& Tang, Y. (2019). Predicting students' academic procrastination in blended learning course using homework submission data. IEEE Access, 7, 102487-102498.

[22]. Alyahyan, E., \& Düştegör, D. (2020). Predicting academic success in higher education: literature review and best practices. International Journal of Educational Technology in Higher Education, 17(1), 3.

[23]. Deng, H., Wang, X., Guo, Z., Decker, A., Duan, X., Wang, C., ... \& Abbott, K. (2019). PerformanceVis: Visual analytics of student performance data from an introductory chemistry course. Visual Informatics, 3(4), 166-176.

[24]. Vialardi, C., Chue, J., Peche, J. P., Alvarado, G., Vinatea, B., Estrella, J., \& Ortigosa, Á. (2011). A data mining approach to guide students through the enrollment process based on academic performance. User modeling and user-adapted interaction, 21(1-2), 217-248.

[25]. Cerezo, R., Bogarín, A., Esteban, M., \& Romero, C. (2020). Process mining for self-regulated learning assessment in e-learning. Journal of Computing in Higher Education, 32(1), 74-88.

[26]. Aydoğdu, Ş. (2020). Predicting student final performance using artificial neural networks in online learning environments. Education and Information Technologies, 25(3), 1913-1927.

[27]. Adejo, O. W., \& Connolly, T. (2018). Predicting student academic performance using multi-model heterogeneous ensemble approach. Journal of Applied Research in Higher Education, 10(1), 61-75.

[28]. Yıldız, O., Bal, A., GŸlseçen, S., \& Kentli, F. D. (2012). A genetic-fuzzy based mathematical model to evaluate the distance education students' academic performance. Procedia-Social and Behavioral Sciences, 55, 409-418.

[29]. Yüce, B., Karahoca, A., \& Karahoca, D. (2011). The use of electronic curriculums in occupational education to evaluate and improve the cognitive capacity of candidate software engineers. Procedia Computer Science, 3, 1418-1424.

[30]. Regueras, L. M., Verdú, M. J., De Castro, J. P., \& Verdú, E. (2019). Clustering Analysis for Automatic Certification of LMS Strategies in a University Virtual Campus. IEEE Access, 7, 137680-137690. 